\title{
A weak relationship between crown architectural and leaf traits in saplings of eight tropical rain forest species, Indonesia
}

Running title: Sapling leaf and crown traits

Key words: Corner's rule, crown architecture, height growth, leaf life span, leaf mass per area, leaf nitrogen, leaf size, sapling

KOICHI TAKAHASHI ${ }^{*}$ and YUMI MIKAMI ${ }^{\dagger}$

*Department of Biology, Faculty of Science, Shinshu University, Matsumoto 390-8621, Japan

${ }^{\dagger}$ Graduate School of Science and Technology, Shinshu University, Matsumoto 390-8621, Japan

Correspondence: Koichi Takahashi

Email: koichit@shinshu-u.ac.jp

Tel: +81.263.37.2533, Fax: +81.263.37.2560 


\begin{abstract}
There are two trade-offs at the levels of leaves and crowns, i.e. assimilation capacity per leaf mass is greater for shorter-lived leaves, and unbranched species grow faster in height by allocating carbon more to trunk than to leaves and branches compared with highly branched species. The hypotheses were tested that the degree of branching $\left(L_{\mathrm{TB}}\right)$ correlates with leaf traits and that height growth rate is negatively correlated with the degree of branching and leaf life span (LLS) by examining saplings of five canopy and subcanopy species, two shrub species and one invasive subshrub species (Clidemia hirta) in a tropical rain forest, West Java, Indonesia. Of the eight species, the most branched and unbranched species were Castanopsis acuminatissima and Macaranga semiglobosa, respectively. Leaf traits examined were leaf size, LLS, leaf mass per area (LMA), leaf nitrogen concentration per mass ( $\left.N_{\text {mass }}\right)$ and per area. LLS tended to be positively correlated with LMA, and negatively correlated with $N_{\text {mass. }}$ Leaf size was negatively correlated with $L_{\mathrm{TB}}$, but the other leaf traits were not correlated with $L_{\mathrm{TB}}$. The height growth of the eight species was low, irrespective of $L_{\mathrm{TB}}$ and LLS, for understorey individuals. The height growth of gap individuals was negatively correlated with LLS for the eight species, and also negatively with $L_{\mathrm{TB}}$ for the seven species other than one subshrub species. Thus, the degree of branching was correlated with leaf size only among the five leaf traits, and both leaf life span and the degree of branching affected the height growth of gap individuals, except for the subshrub species.
\end{abstract}




\section{INTRODUCTION}

Light is one of the most important resources for understorey saplings in forest ecosystems. The relative light intensity on a forest floor is only a few per cent in tropical rain forests (Chazdon \& Fetcher 1984, Pearcy 1983, Yoda 1974). Understorey saplings must survive in the light-limited conditions until a canopy gap is created, and must grow rapidly after gap formation to outcompete other saplings (Canham 1988, Poulson \& Platt 1996, Takahashi 1996). Most saplings die before growing to the reproductive stage, according to survivorship curves of tree species (Kohyama \& Fujita 1981, Nakashizuka 1991). Thus, the sapling stage is important in the life history of tree species (Messier et al. 1999).

For growth and survival, saplings must have photosynthetic production, which is determined by total leaf area per sapling and assimilation rates per unit leaf area (Lambers \& Poorter 1992, Poorter \& Remkes 1990, Takahashi et al. 2001). Crown architecture is one of the factors affecting sapling leaf area. The crown architecture of saplings can be divided into two extreme: unbranched and highly branched types (Kohyama 1987, Kohyama \& Hotta 1990). Highly branched species develop their crowns by allocating carbon more to leaves and branches than to the trunk compared with unbranched species. The developed crown is advantageous for survival in the understorey because of a large assimilative area (Sterck et al. 2003). By contrast, the height growth rate of unbranched species is greater than that of highly branched species because a lower biomass increment is required per unit height growth for the unbranched species (Coomes \& Grubb 1998, Kohyama 1987). Unbranched species tend to have a small number of large leaves (Kohyama 1987, Takahashi \& Rustandi 2006, 
Takahashi et al. 2001). Corner's rules suggested that (1) the stouter the stem, the bigger the leaves and the more complicated their form, and (2) the greater the ramification, the smaller become the branches and their appendages (Corner 1949, Hallé et al. 1978, White 1983). Thus, the combination of the degree of branching and leaf size agrees with Corner's second rule. Large individual leaves compensate for a small number of shoots, and a low leaf support cost (leaf-support tissue mass per unit leaf area) contributes to efficient height growth of unbranched species. Thus, interspecific variation in the degree of branching, as a crown architectural trait, is important for growth and survival of saplings.

Leaf traits are important for carbon gain at the level of individual leaves. Interspecific variation in leaf life span is large spanning a few months to more than $10 \mathrm{y}$, and relates to the leaf morphology and physiology (Chabot \& Hicks 1982, Koike 1988, Reich et al. 1992). Generally, shorter-lived leaves are thinner, and have greater leaf nitrogen per mass ( $\left.N_{\text {mass }}\right)$ and assimilative capacity (Reich et al. 1991, 1992). $N_{\text {mass }}$ is positively correlated with the mass-based assimilation capacity (Ellsworth \& Reich 1992, 1993), because photosynthetic enzymes, such as RuBP carboxylase, contain large quantities of nitrogen (Evans 1989, Seemann et al. 1987). The long photosynthetically active period of long-lived leaves compensates for their low assimilative capacity (Kudo 1999). Given the high assimilation capacity of shorter-lived leaves, the height growth of saplings with shorter-lived leaves is expected to be greater in the light. However, saplings with short-lived leaves must produce many leaves to maintain the current sapling leaf area. If the carbon gain of a sapling is lower than the minimum biomass required to maintain the current sapling leaf area, the growth of the sapling gradually decreases. Such high minimum growth is disadvantageous for the survival in 
understorey conditions where carbon gain is limited (King 1994). Therefore, the crown architectural and leaf traits strongly influence the growth and survival of saplings.

Interspecific variation in the degree of branching may correlate with that in the leaf traits. If unbranched species have short-lived large leaves, their saplings can grow in height rapidly in canopy gaps by the combination of large carbon allocation to the trunk and large assimilative capacity of leaves. By contrast, if highly branched species have long-lived small leaves, combination of a large assimilative area with long-lived leaves is advantageous for survival in light-limited understorey conditions. Takahashi et al. (2005) examined eight deciduous broad-leaved species and observed that mid-successional unbranched species tend to have larger leaves with higher $N_{\text {mass }}$ and thinner leaves as compared with highly branched late-successional species. However, the relationship between the degree of branching and leaf traits other than leaf size was rather weak (Takahashi et al. 2005), probably because the small interspecific variation in leaf life span due to the deciduous habit reduces the interspecific variation of leaf traits such as leaf mass per area (cf. Klooster et al. 2007). Thus, examination of evergreen species with large variation in leaf life span is important to understand the relationship between degree of branching and leaf traits associated with the leaf life span.

This study clarified (1) if leaf traits correlate with degree of branching and (2) if both degree of branching and leaf life span correlate with height growth rates by investigating interspecific variation in leaf traits of leaf life span, leaf nitrogen, leaf mass per area and leaf size in relation to degree of branching in eight evergreen species in a tropical rain forest, Indonesia. 


\section{STUDY SITE}

This study was done in a tropical montane rain forest in Gunung Halimun National Park ( $6^{\circ} 44^{\prime} \mathrm{S}, 106^{\circ} 32^{\prime} \mathrm{E}, 1100 \mathrm{~m}$ asl), West Java, Indonesia. The annual mean rainfall was $3869 \mathrm{~mm}$, recorded at the office of a tea plantation near the study site during 1998 to 2002. The rainy season is from October to April, and the monthly rainfall exceeds 300 mm during this period. The monthly mean temperatures were between $24^{\circ} \mathrm{C}$ and $31^{\circ} \mathrm{C}$ in 1998 and 1999 (Takahashi \& Mikami 2006).

The forest of the Gunung Halimun National Park was a reserve, and, therefore, anthropogenic effects on the vegetation were absent. Two permanent plots, $100 \times 100 \mathrm{~m}$ in area, were established on Mount Kendung (Suzuki et al. 1997, 1998). The number of tree species greater than $4.8 \mathrm{~cm}$ dbh in the two plots was 116 and 103 species, the total basal area was $36.3 \mathrm{~m}^{2} \mathrm{ha}^{-1}$ and $35.4 \mathrm{~m}^{2} \mathrm{ha}^{-1}$, respectively, and the maximum tree heights were $54 \mathrm{~m}$ and $37 \mathrm{~m}$, respectively. The dominant species in the two plots were Altingia excelsa Noronha, Castanopsis acuminatissima A. DC. ex Hance, Schima wallichii Choisy and Quercus lineata Blume (Suzuki et al. 1997, 1998). Several ginger species dominated the forest floor (Nishimura \& Suzuki 2000, Takahashi 2004).

\section{MATERIALS AND METHODS}

\section{Field methods}

Eight species were chosen for analysis (Table 1), because these species were abundant compared with other species. The crown architecture differed between the eight species, 
i.e. their branching structure varied between unbranched and highly developed types (Takahashi \& Rustandi 2006). Castanopsis acuminatissima was the most-branched species, and Macaranga semiglobosa J. J. S. was the most unbranched species (Table 1). Adult size differed among the eight species (Table 1). Lasianthus tomentosus $\mathrm{Bl}$. and Symplocos cochinchinesis (Lour.) Moore. ssp. laurina (Retz.) Noot. are shrub species. M. semiglobosa is a subcanopy tree species. Clidemia hirta (L.) D. Don is an invasive subshrub species, native to Central and South America (Wester \& Wood 1977). The other species were canopy tree species.

Takahashi \& Rustandi (2006) examined the crown allometry and height growth of understorey and gap individuals shorter than $2.5 \mathrm{~m}$ of the eight species used in this study. They examined about 40 individuals of each of the eight species. In this study, we examined the leaf traits of these understorey and gap individuals in relation to the degree of branching found by Takahashi \& Rustandi (2006).

All leaves were counted for each individual in March 2003, and were marked with a paint marker. All leaves of each individual were counted again and newly emerged leaves were marked with a paint marker in October 2003 and March 2004. The leaf life span (LLS, y) of each individual was calculated by the following equation (King 1994).

$$
\mathrm{LLS}=\frac{2 \times N_{M}}{R_{P}+R_{L}},
$$

where $N_{M}$ is the mean number of leaves per plant, $R_{P}$ is the leaf production rate per plant and $R_{L}$ is the leaf loss rate per plant. The number of leaves in March 2003 and March 2004 was used for the calculation.

We collected several leaves from the leader shoot of each individual in March 
2004. The leaves were oven-dried for at least 24 hour at $80^{\circ} \mathrm{C}$ and were weighed. The leaf area was measured by using the computer graphic software NIH Image and a scanner. Petioles were not included in estimated leaf areas. The mean leaf area of individual leaves was calculated for each species. After the leaf area was measured, the leaves were ground into a powder and the nitrogen concentration per leaf dry mass ( $\left.N_{\text {mass }}\right)$ was determined by using a C-N analyzer (MT-1600, Yanaco Co., Tokyo). The nitrogen concentration per leaf area ( $\left.N_{\text {area }}\right)$ was calculated by the product of $N_{\text {mass }}$ and leaf mass per area (LMA).

\section{Statistical analysis}

Takahashi \& Rustandi (2006) showed three allometric relationships relating to crown development: total leaf area per individual plant $\left(A_{\mathrm{L}}\right)$, crown projection area $\left(A_{\mathrm{C}}\right)$, and total length of trunk and branches $\left(L_{\mathrm{TB}}\right)$, each against trunk height. Trunk height was defined as vertical distance from the ground to the highest apex, i.e. trunk height is equivalent to plant height. $L_{\mathrm{TB}}$ was used to express the degree of branching at a given trunk height. Takahashi \& Rustandi (2006) compared the interspecific differences of the crown allometry at trunk heights 45, 90 and $180 \mathrm{~cm}$. The interspecific differences were pronounced at $180 \mathrm{~cm}$ because more species differences were found on slopes of the log-log allometry than on the intercepts. Thus, in this study we used $L_{\mathrm{TB}}$ at the trunk height of $180 \mathrm{~cm}$ to represent the degree of branching of each species. Takahashi \& Rustandi (2006) also showed that $A_{\mathrm{L}}$ and $A_{\mathrm{C}}$ were positively correlated with $L_{\mathrm{TB}}$ at trunk height $180 \mathrm{~cm}$, indicating that highly branched species have well-developed crowns.

The effects of leaf life span, canopy conditions (gap vs understorey) and the 
interaction on leaf traits LMA, $N_{\text {mass }}, N_{\text {area, }}$ leaf size and height growth rate were examined by general linear models. The mean leaf area of individual leaves was used as the leaf size for each species in each canopy condition. The canopy condition was treated as a categorical variable. The effects of $L_{\mathrm{TB}}$ at trunk height $180 \mathrm{~cm}$, canopy conditions (gap vs understorey) and the interaction on leaf traits LMA, $N_{\text {mass }}, N_{\text {area }}$, leaf size, leaf life span and height growth rate were also examined by general linear models.

\section{RESULTS}

Interspecific variation in two leaf traits of the four was significantly correlated with leaf life span. LMA was positively $(\mathrm{P}<0.01)$ and $N_{\text {mass }}$ was negatively $(\mathrm{P}<0.01)$ correlated with leaf life span (Figure 1a, b, Table 2). However, LMA and $N_{\text {mass }}$ were hardly affected by canopy conditions (gap vs understorey) and the interaction between canopy conditions and leaf life span (Figure 1a, b, Table 2). Canopy conditions (gap vs understorey), leaf life span and the interaction did not affect on leaf size and $N_{\text {area }}$ (Table 2). Thus, shorter-lived leaves had higher $N_{\text {mass }}$ and lower LMA, irrespective of canopy conditions.

The five leaf traits were examined in relation to canopy conditions and the degree of branching expressed as the $L_{\mathrm{TB}}$ at $180 \mathrm{~cm}$ trunk height. Leaf life span, LMA, $N_{\text {mass }}$ and $N_{\text {area }}$ were not significantly affected by canopy conditions and $L_{\text {TB }}$ (Table 3 ). However, leaf size was negatively correlated with $L_{\text {тв }}$ (Figure 2, Table 3, P $<0.01$ ). Thus, the relationships of leaf traits and degree of branching were weak, except for those involving leaf size.

The height growth rate of understorey individuals of the eight species was low, 
irrespective of $L_{\mathrm{Tв}}$ and leaf life span (Figure 3a, b). However, the effects of canopy conditions ( $\mathrm{P}<0.001)$, leaf life span $(\mathrm{P}<0.01)$ and the interaction $(\mathrm{P}<0.01)$

significantly affected the height growth rate (Figure 3b, Table 2), indicating that species with shorter-lived leaves grew faster in gaps. The effects of the degree of branching ( $\left.L_{\mathrm{TB}}\right)$ and the interaction between $L_{\mathrm{TB}}$ and canopy conditions were not significant, indicating that the height growth rate increased in gaps, irrespective of $L_{\mathrm{TB}}$ (Figure 3a, Table 3). However, when the invasive subshrub species Clidemia hirta was excluded, the effect of $L_{\mathrm{TB}}$ on the height growth was significant in the other seven species $\left(F_{1,10}=\right.$ 5.9, $\mathrm{P}<0.05)$.

\section{DISCUSSION}

In this study, leaf life span was positively correlated with LMA and negatively correlated with $N_{\text {mass }}$ among the eight species, irrespective of canopy conditions (gap and understorey). These relationships are general patterns, irrespective of growth form, plant functional type or biome (Wright et al. 2004), because long-lived leaves must be mechanically strengthened and short-lived leaves need much nitrogen for a positive carbon balance (carbon gain by photosynthesis minus leaf construction cost) during the leaf life span. Although this study examined only eight species, the leaf traits in relation to leaf life span agreed with previous studies (Mediavilla \& Escudero 2003, Reich et al. 1991, 1992, Shipley et al. 2006).

We expected a relationship between leaf traits and crown architectural traits, i.e. unbranched species have short-lived large thin leaves with high assimilative capacity (low LMA and high $N_{\text {mass }}$ ) and highly branched species have long-lived small thick 
leaves with low assimilative capacity (high LMA and low $N_{\text {mass }}$ ). However, the degree of branching was not correlated with leaf traits, except for leaf size, indicating weak relationships between crown architectural and leaf traits.

Shade tolerance of tropical trees is positively correlated with LMA and leaf life span, and is negatively correlated with $N_{\text {mass }}$ and maximum photosynthetic rate $\left(A_{\max }\right)$ (Baltzer \& Thomas 2007, Poorter \& Bongers 2006, Sterck et al. 2006a). Shade tolerance is also positively correlated with crown architectural traits, such as wood density, crown projection area and total leaf area per plant (Henry \& Aarssen 2001, Sterck et al. 2006b, Takahashi et al. 2001). Leaf traits relate to light requirement for each species because high $A_{\max }$ is associated with a high respiration rate, which is disadvantageous for survival in understorey conditions. Total leaf area per plant relates to assimilation area per plant (Takahashi et al. 2001). Thus, in this study, the negative correlation between height growth and leaf life span for gap individuals of the eight species is because assimilative capacity per leaf mass is greater for leaves with a shorter life span (Koike 1988, Reich et al. 1991). Also, the negative correlation between height growth rate and the degree of branching is, but only if Clidemia hirta was excluded, due to lower biomass increment required per unit height growth for unbranched species than highly branched species (Kohyama 1987). Therefore, crown architectural and leaf traits influence the height growth of the eight species, except for Clidemia hirta in terms of the effect of the degree of branching.

Clidemia hirta is a weedy aggressive invasive species which shades out all vegetation below it, and often dominates in disturbed sites such as along trails and after wild fire (Wester \& Wood 1977). In addition, the rate of the increase of height growth rate in gaps is greater in Clidemia hirta than the seven other species (Takahashi \& 
Rustandi 2006), nevertheless this species is not unbranched. One would expect that invasive species grow faster in introduced sites than the native sites because invasive species lack coevolved enemies in their new ranges, i.e. enemy-release hypothesis (Elton 1958, Mitchell \& Power 2003). However, Parker et al. (2006) examined more than 100 species to test this hypothesis, and found that native herbivores suppressed exotic plants. Thus, the enemy-release hypothesis is still controversial. Genetic shift is another hypothesis to explain successful invasion of invasive species, i.e. native and introduced genotypes differ genetically in ways that lead to differences in biomass allocation, growth or photosynthesis (Blossey \& Nötzold 1995). However, DeWalt et al. (2004) revealed that there were no significant differences in relative growth rates, maximal photosynthetic rates and LMA of Clidemia hirta between introduced and native sites. Thus, the high growth rate of Clidemia hirta in gaps cannot be explained by the enemy-release and genetic-shift hypotheses. Assimilative capacity of Clidemia hirta leaves is probably greatest among the eight species because of the shortest leaf life span associated with the highest $N_{\text {mass }}$ (Figure 3b). Furthermore, Clidemia hirta does not need to construct thick stem associated with high wood density because Clidemia hirta is a perennial subshrub (i.e. almost herbaceous species). It is no doubt that the high growth rate of Clidemia hirta in gaps is caused by the low wood density and thin stem in addition to the high assimilative capacity of the leaves. Therefore, Clidemia hirta is an exceptional species for the analysis of the relationship between height growth rate and the degree of branching.

Height growth of understorey individuals of the eight species was low, irrespective of the degree of branching and leaf life span, unlikely as in the interspecific variation in gap individuals. A similar pattern was also reported by Coomes \& Grubb 
(1998) for 12 Amazonian species, i.e. height growth rates of understorey saplings were similar among the 12 species, irrespective of the degree of branching, while unbranched species tended to grow faster in gaps than branched species. Thus, the interspecific variations of height growth between gap and understorey contrast sharply with those of the leaf traits (LMA and $N_{\text {mass }}$ ) that the interspecific variations were explained well by the leaf life span, irrespective of canopy conditions. Similar growth rates of understorey individuals among the eight species were probably because of the shortage of light resource for assimilation, i.e. species could not assimilate at the maximal rate. Unbranched species can potentially grow in height faster than highly branched species because lower biomass is required for unit height growth. However, total leaf area of unbranched species is smaller than highly branched species in understorey conditions (Takahashi \& Rustandi 2006), which reduces carbon gain per plant in unbranched species. Thus, the lower cost for height growth was counterbalanced by a smaller total leaf area in unbranched species, which resulted in similar height growth rates among the eight species with different degrees of branching in understorey conditions.

Of the several leaf traits examined, only individual leaf size was negatively correlated with $L_{\mathrm{TB}}$, i.e. Corner's second rule - the greater the ramification, the smaller the branches and their appendages (Corner 1949). Such weak relationships between the degree of branching and leaf traits (LMA and $N_{\text {mass }}$ ) were also observed in saplings of deciduous broad-leaved species, while Corner's rule was recognized in these species (Takahashi et al. 2001, 2005). Ackerly \& Donoghue (1998) found that 17 Acer species in the understorey were arranged by independent morphological suits, i.e. Corner's rule and crown allometry. They argued for relatively independent evolution of two suits of traits. Although the results of this study cannot be simply compared with those of 
Ackerly \& Donoghue (1998) because the leaf and crown traits examined were different between the two studies, the negative relationship between leaf size and degree of branching may be an evolutionally robust character. The number of leaves per plant is regulated by the number of shoots per plant. In unbranched species with a fewer shoots, leaf size of individual leaves should be larger to increase the total leaf area per plant. If the leaf size of highly branched species with many shoots is as large as that of unbranched species with a few shoots branches, total leaf area per plant increases much, which decreases the whole-plant carbon gain due to severe self-shading within a crown (Pearcy \& Yang 1998, Takenaka et al. 2001). King (1998) observed that first branch height was positively correlated with leaf size in 70 species in tropical rain forests, showing that leaf size correlates with crown architecture. Thus, strong selection pressure could drive on the leaf size/number and the degree of branching. Therefore, the negative relationship between the degree of branching and leaf size (i.e. Corner's rule) is efficient for whole-plant carbon gain, irrespective of leaf life span.

This study concludes (1) that degree of branching did not correlate with the leaf traits except for leaf size in the eight species (only a negative relationship between the degree of branching and leaf size was recognized), and (2) that the height growth rate of gap individuals was negatively correlated with leaf life span for the eight species and with the degree of branching for the seven species other than the subshrub Clidemia hirta. We predicted that the shade tolerance of the species would be highest if highly branched species have long-lived small leaves with high LMA and low $N_{\text {mass, }}$ and the growth in gaps is highest if an unbranched form is coupled with short-lived large leaves with low LMA and high $N_{\text {mass }}$. Thus, the relationships between the crown architectural and leaf traits were weaker than our prediction in the eight species examined. It is 
necessary to examine how such a weak correlation between leaf and crown architectural traits contributes to the regeneration of the eight species and the maintenance of species diversity in this forest.

\section{ACKNOWLEDGEMENTS}

We are grateful to Agus Rustandi, Muhammad Amir and Aden Muhidin for their assistance in the field. Thanks are also due to the staff of the Research and Development Center for Biology, Indonesian Institute of Science for their kind support. This study was made by permission of the Indonesian Institute of Science (LIPI). The field study was financially supported by a grant from the Ministry of Education, Culture, Sports, Science and Technology, Japan (No. 14255003, Leader T. Kohyama).

\section{LITERATURE CITED}

ACKERLY, D. D. \& DONOGHUE, M. J. 1998. Leaf size, sapling allometry, and Corner's rules: phylogeny and correlated evolution in maples (Acer). American Naturalist 152:767-791.

BALTZER, J. L. \& THOMAS, S. C. 2007. Determinants of whole-plant light requirements in Bornean rain forest tree saplings. Journal of Ecology 95:1208-1221.

BLOSSEY, B. \& NÖTZOLD, R. 1995. Evolution of increased competitive ability in invasive nonindigenous plants: a hypothesis. Journal of Ecology 83:887-889.

CANHAM, C. D. 1988. Growth and canopy architecture of shade-tolerant trees: 
response to canopy gaps. Ecology 69:786-795.

CHABOT, B. F. \& HICKS, D. J. 1982. The ecology of leaf life spans. Annual Review of Ecology and Systematics 13:229-259.

CHAZDON, R. L. \& FETCHER, N. 1984. Photosynthetic light environments in a lowland tropical rain forest in Costa Rica. Journal of Ecology 72:553-564.

COOMES, D. A. \& GRUBB, P. J. 1998. A comparison of 12 tree species of Amazonian caatinga using growth rates in gaps and understorey, and allometric relationships. Functional Ecology 12:426-435.

CORNER, E. J. H. 1949. The durian theory or the origin of the modern tree. Annals of Botany 13:367-414.

DEWALT, S. J., DENSLOW, J. S. \& HAMRICK, J. L. 2004. Biomass allocation, growth, and photosynthesis of genotypes from native and introduced ranges of the tropical shrub Clidemia hirta. Oecologia 138:521-531.

ELLSWORTH, D. S. \& REICH, P. B. 1992. Leaf mass per area, nitrogen content and photosynthetic carbon gain in Acer saccharum seedlings in contrasting forest light environments. Functional Ecology 6:423-435.

ELLSWORTH, D. S. \& REICH, P. B. 1993 Canopy structure and vertical patterns of photosynthesis and related leaf traits in a deciduous forest. Oecologia 96:169-178.

ELTON, C. S. 1958. The ecology of invasions of animals and plants. Methuen, London. 181 pp.

EVANS, J. R. 1989. Photosynthesis and nitrogen relationships in leaves of $\mathrm{C}_{3}$ plants. Oecologia 78:9-19.

HALLÉ, F., OLDEMAN, R. A. A. \& TOMLINSON, P. B. 1978. Tropical trees and 
forests. An architectural analysis, Springer-Verlag, Berlin. 441 pp.

HENRY, H. A. L. \& AARSSEN, L. W. 2001. Inter- and intraspecific relationships between shade tolerance and shade avoidance in temperate trees. Oikos 93:477-487.

KING, D. A. 1994. Influence of light level on the growth and morphology of saplings in a Panamanian forest. American Journal of Botany 81:948-957.

KING, D. A. 1998. Influence of leaf size on tree architecture: first branch height and crown dimensions in tropical rain forest trees. Trees 12:438-445.

KLOOSTER, S. H. J., THOMAS, E. J. P. \& STERCK, F. J. 2007. Explaining interspecific differences in sapling growth and shade tolerance in temperate forests. Journal of Ecology 95:1250-1260.

KOHYAMA, T. 1987. Significance of architecture and allometry in saplings. Functional Ecology 1:399-404.

KOHYAMA, T. \& FUJITA, N. 1981. Studies on the Abies population of Mt. Shimagare I. Survivorship curve. Botanical Magazine, Tokyo 94:55-68.

KOHYAMA, T. \& HOTTA, M. 1990. Significance of allometry in tropical saplings. Functional Ecology 4:515-521.

KOIKE, T. 1988. Leaf structure and photosynthetic performance as related to the forest succession of deciduous broad-leaved trees. Plant Species Biology 3:77-87.

KUDO, G. 1999. A review of ecological studies on leaf-trait variations along environmental gradients - in the case of tundra plants. Japanese Journal of Ecology 49:21-35. (in Japanese)

LAMBERS, H. \& POORTER, H. 1992. Inherent variation in growth rate between higher plants: a search for physiological causes and ecological consequences. 
Advances in Ecological Research 23: 187-261.

MEDIAVILLA, S. \& ESCUDERO, A. 2003. Photosynthetic capacity, integrated over the lifetime of a leaf, is predicted to be independent of leaf longevity in some tree species. New Phytologist 159:203-211.

MESSIER, C., DOUCET, R., RUEL, J-C., CLAVEAU, Y., KELLY, C. \& LECHOWICZ, M. J. 1999. Functional ecology of advance regeneration in relation to light in boreal forests. Canadian Journal of Forest Research 29:812-823.

MITCHELL, C. E. \& POWER, A. G. 2003. Release of invasive plants from functional and viral pathogens. Nature 421: 625-627.

NAKASHIZUKA, T. 1991. Population dynamics of coniferous and broad-leaved trees in a Japanese temperate mixed forest. Journal of Vegetation Science 2:413-418.

NISHIMURA, T. B. \& SUZUKI, E. 2000. Spatial distributions of ginger species at tropical submontane forest floor. Tropics 20:103-116.

PARKER, J. D., BURKEPILE, D. E. \& HAY, M. E. 2006. Opposing effects of native and exotic herbivores on plant invasions. Science 311:1459-1461.

PEARCY, R. W. 1983. The light environment and growth of $\mathrm{C}_{3}$ and $\mathrm{C}_{4}$ tree species in the understorey of a Hawaiian forest. Oecologia 58:19-25.

PEARCY, R. W. \& YANG, W. 1998. The functional morphology of light capture and carbon gain in the Redwood forest understory plant Adenocaulon bicolor Hook. Functional Ecology 12:543-552.

POORTER, L. \& BONGERS, F. 2006. Leaf traits are good predictors of plant performance across 53 rain forest species. Ecology 87:1733-1743.

POORTER, H. \& REMKES, C. 1990. Leaf area ratio and net assimilation rate of 24 
wild species differing in relative growth rate. Oecologia 83:553-559.

POULSON, T. L. \& PLATT, W. J. 1996. Replacement patterns of beech and sugar maple in Warren Woods, Michigan. Ecology 77:1234-1253.

REICH, P. B., UHL, C., WALTERS, M. B. \& ELLSWORTH, D. S. 1991. Leaf lifespan as a determinant of leaf structure and function among 23 Amazonian tree species. Oecologia 86:16-24.

REICH, P. B., WALTERS, M. B. \& ELLSWORTH, D. S. 1992. Leaf life-span in relation to leaf, plant, and stand characteristics among diverse ecosystems. Ecological Monographs 62:365-392.

SEEMANN, J. R., SHARKEY, T. D., WANG, J. \& OSMOND, C. B. 1987. Environmental effects on photosynthesis, nitrogen-use efficiency, and metabolic pools in leaves of sun and shade plants. Plant Physiology 84:769-802.

SHIPLEY, B., LECHOWICZ, M. J., WRIGHT, I. \& REICH, P. B. 2006. Fundamental trade-offs generating the worldwide leaf economics spectrum. Ecology $87: 535-541$.

STERCK, F., MARTINÉZ-RAMOS, M., DYER-LEAL, G., RODRÍGUEZ-VELAZQUEZ, J. \& POORTER, L. 2003. The consequences of crown traits for the growth and survival of tree saplings in a Mexican lowland rainforest. Functional Ecology 17:194-200.

STERCK, F. J., POORTER, L. \& SCHIEVING, F. 2006a. Leaf traits determine the growth-survival trade-off across rain forest tree species. American Naturalist $167: 758-765$.

STERCK, F. J., VAN GELDER, H. A. \& POORTER, L. 2006b. Mechanical branch constraints contribute to life-history variation across tree species in a Bolivian 
forest. Journal of Ecology 94:1192-1200.

SUZUKI, E., YONEDA, M., SIMBOLON, H., MUHIDIN, A. \& WAKIYAMA, S. 1997. Establishment of two 1-ha permanent plots in Gunung Halimun National Park for study of vegetation structure and forest dynamics. Pp. 36-55 in Yoneda, M., Sugardjito, J. \& Simbolon, H. (eds.). Research and conservation of biodiversity in Indonesia. Vol. II. The inventory of natural resources in Gunung Halimun National Park. LIPI, JICA \& PHPA, Bogor.

SUZUKI, E., YONEDA, M., SIMBOLON, H., FANANI, Z., NISHIMURA, T. \& KIMURA, M. 1998. Monitoring of vegetation changes on permanent plots in Gunung Halimun National Park. Pp. 60-81 in Simbolon, H., Yoneda, M. \& Sugardjito, J. (eds.) Research and conservation of biodiversity in Indonesia. Vol. IV. Gunung Halimun: the last submontane tropical forest in West Java. LIPI, JICA and PHPA, Bogor.

TAKAHASHI, K. 1996. Plastic response of crown architecture to crowding in understorey trees of two co-dominating conifers. Annals of Botany 77:159-164.

TAKAHASHI, K. 2004. Crown architecture of the ginger Alpinia scabra (Zingiberaceae) in a tropical submontane forest, Indonesia. Tropics 14:65-73.

TAKAHASHI, K. \& MIKAMI, Y. 2006. Effects of canopy cover and seasonal reduction in rainfall on leaf phenology and leaf traits of the fern Oleandra pistillaris in a tropical montane forest, Indonesia. Journal of Tropical Ecology 22:599-604.

TAKAHASHI, K. \& RUSTANDI, A. 2006. Responses of crown development to canopy openings by saplings of eight tropical submontane forest tree species in Indonesia: a comparison with cool temperate trees. Annals of Botany 97:559-569. 
TAKAHASHI, K., SEINO, T. \& KOHYAMA, T. 2001. Responses to canopy openings in architectural development of saplings in eight deciduous broad-leaved tree species. Canadian Journal of Forest Research 31:1336-1347.

TAKAHASHI, K., SEINO, T. \& KOHYAMA, T. 2005. Plastic changes of leaf mass per area and leaf nitrogen content in response to canopy openings in saplings of eight deciduous broad-leaved tree species. Ecological Research 20:17-23.

TAKENAKA, A., TAKAHASHI, K. \& KOHYAMA, T. 2001. Optimal leaf display and biomass partitioning for efficient light capture in an understorey palm, Licuala arbuscula. Functional Ecology 15:660-668.

WESTER, L. L. \& WOOD, H. B. 1977. Koster's curse (Clidemia hirta), a weed pest in Hawaiian forests. Environmental Conservation 4:35-41.

WHITE, P. S. 1983. Corner's rules in eastern deciduous trees: allometry and its implications for the adaptive architecture of trees. Bulletin of the Torrey Botanical Club 110:203-202.

WRIGHT, I. J., REICH, P. B., WESTBY, M., ACKERLY, D. D., BARUCH, Z., BONGERS, F., CAVENDER-BARES, J., CHAPIN, T., CORNELISSEN, J. H. C., DIEMER, M., FLEXAS, J., GARNIER, E., GROOM, P. K., GULIAS, J., HIKOSAKA, K., LAMONT, B. B., LEE, T., LEE, W., LUSK, C., MIDGLEY, J. J., NAVAS, M.-L., NIINEMETS, Ü., OLEKSYN, J., OSADA, N., POORTER, H., POOT, P., PRIOR, L., PYANKOV, V. I., ROUMET, C., THOMAS, S. C., TJOELKER, M. G., VENEKLAAS, E. J. \& VILLAR, R. 2004. The worldwide leaf economics spectrum. Nature 428:821-827.

YODA, K. 1974. Three-dimensional distribution of light intensity in a tropical rain forest of west Malaysia. Japanese Journal of Ecology 24:247-254. 


\section{Figure legends}

Figure 1. Relationships of LMA (a) and $N_{\text {mass }}$ (b) with leaf life span among eight species in a tropical montane forest, Indonesia. Solid and open circles represent understorey and gap individuals, respectively. The results of statistical tests are shown in Table 2 .

Figure 2. Relationship between leaf size and total length of trunk and branches $\left(L_{\mathrm{TB}}\right)$ at $180 \mathrm{~cm}$ trunk height among eight species in a tropical montane forest, Indonesia. Solid and open circles represent understorey and gap individuals, respectively. The result of statistical test is shown in Table 3.

Figure 3. Relationships of height growth rate with ln-transformed $L_{\mathrm{TB}}($ a) and leaf life span (b) among eight species in a tropical montane forest, Indonesia. Solid and open circles represent understorey and gap individuals, respectively. The results of statistical tests are shown in Tables 2 and 3. $\mathrm{Cl}=$ Clidemia hirta . 

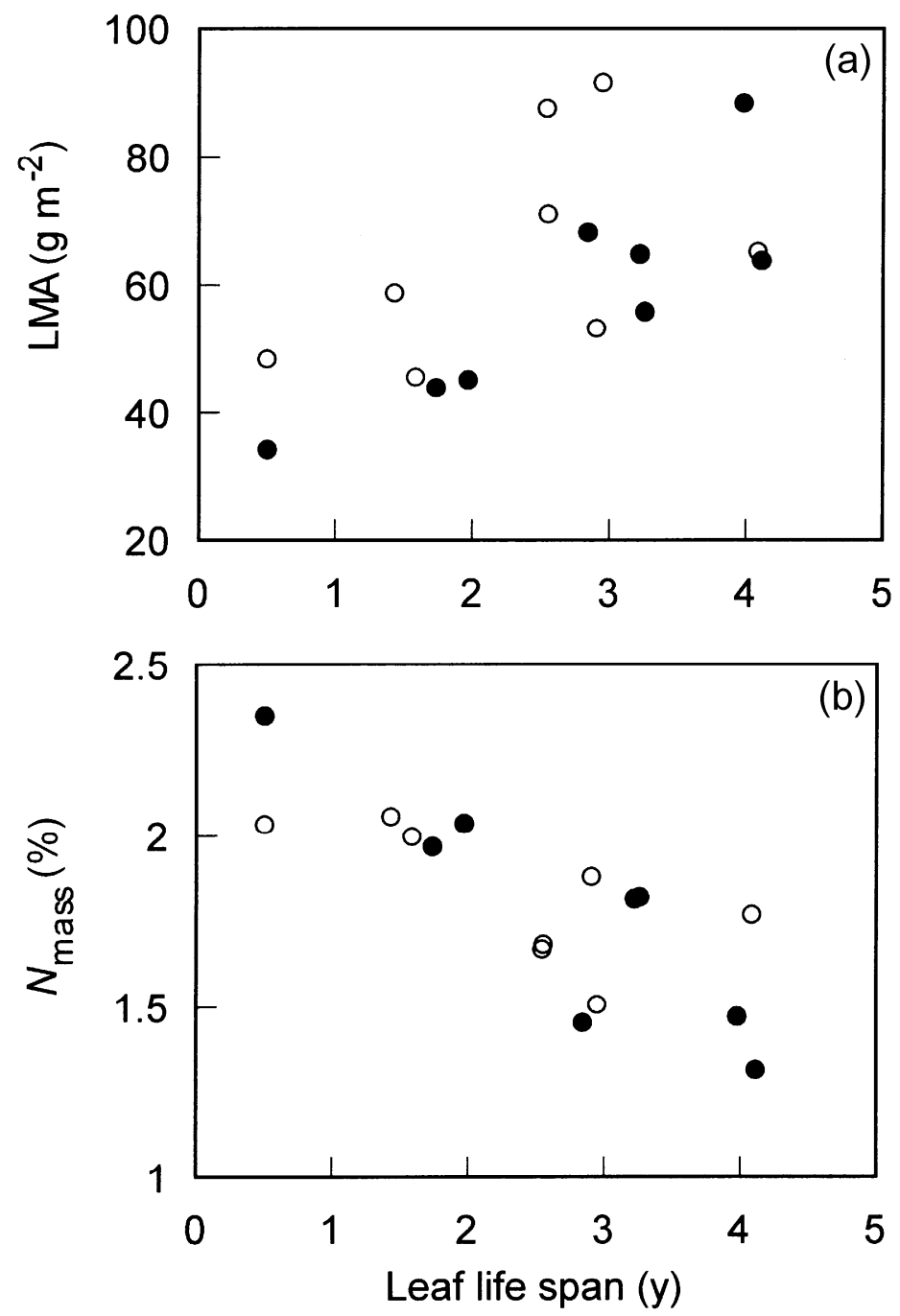

Figure 1 


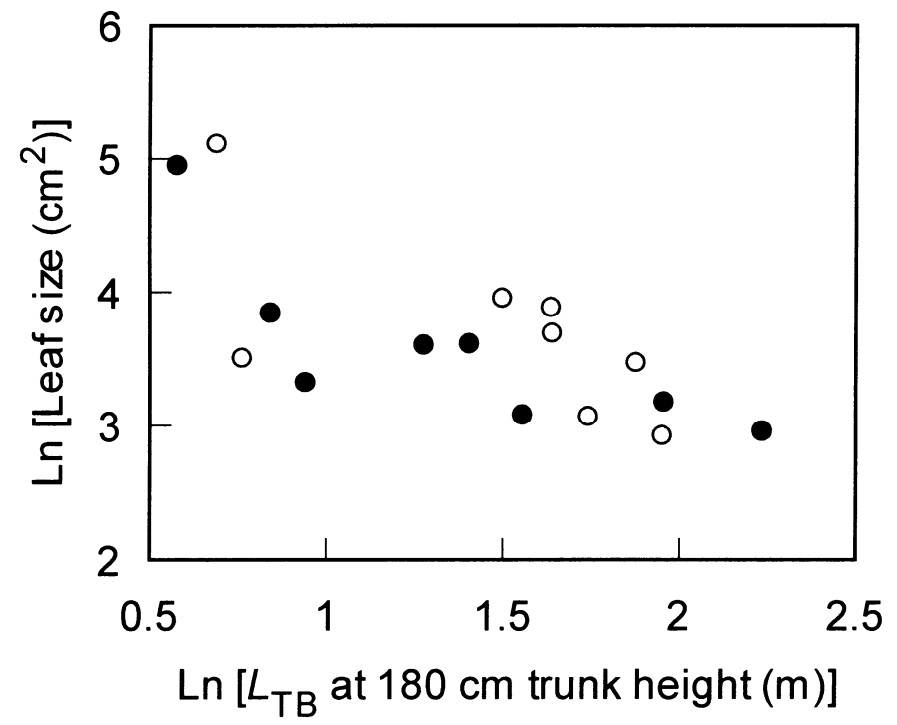

Figure 2 

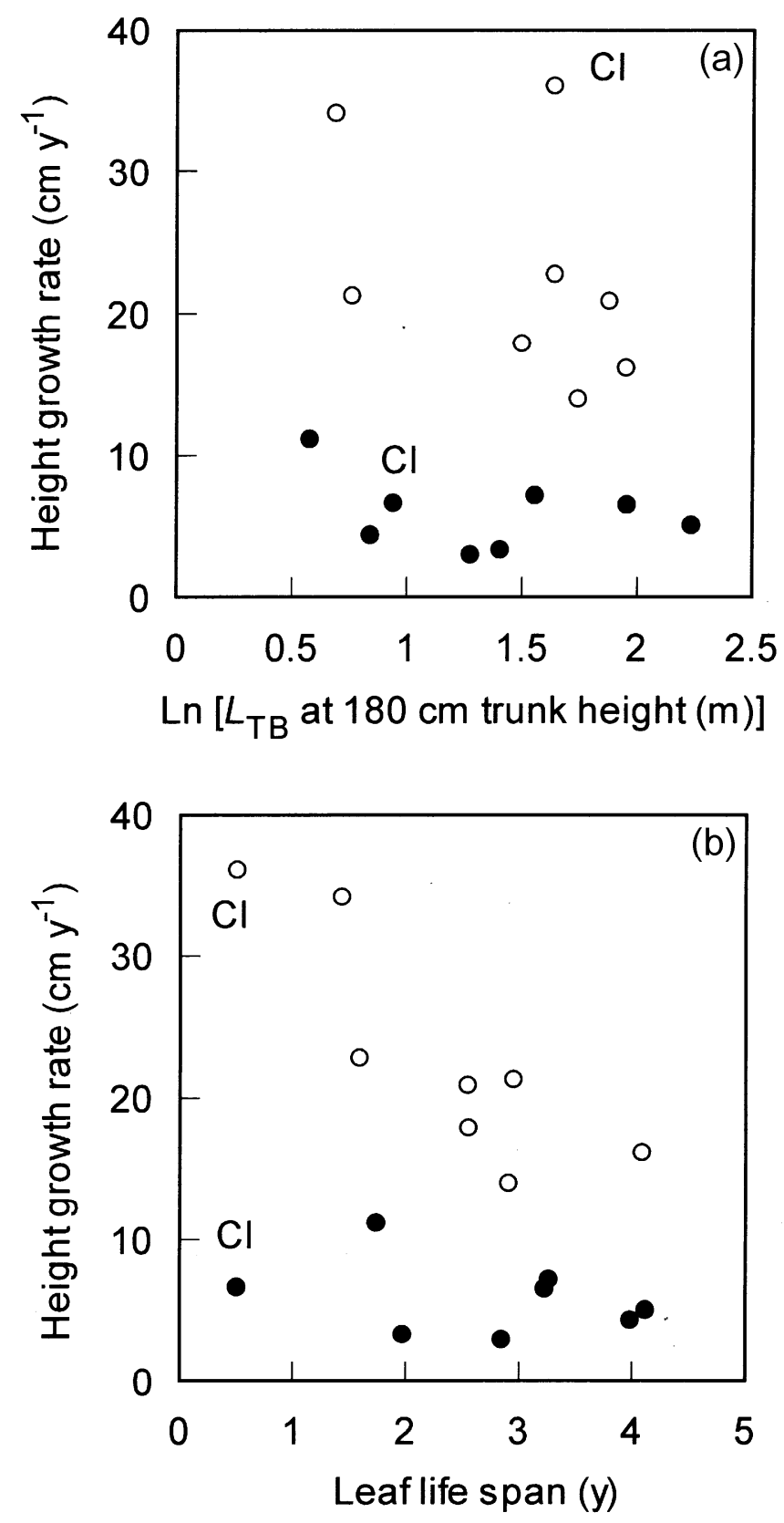

Figure 3 
Table 1. Characteristics of saplings of eight species in a tropical montane forest, Indonesia. Species are arranged in descending order by degree of branching. $U=$ understorey conditions, $\mathrm{G}$ = canopy gap conditions. $\mathrm{C}=$ Canopy species, $\mathrm{SC}=$ subcanopy species, $\mathrm{S}=$ shrub species, $\mathrm{SS}=$ subshrub species.

\begin{tabular}{|c|c|c|c|c|c|c|c|c|}
\hline \multirow[b]{2}{*}{ Species } & & \multicolumn{2}{|c|}{ Sample size } & \multirow{2}{*}{$\begin{array}{l}\text { Height } \\
\text { range } \\
(\mathrm{cm})\end{array}$} & \multirow{2}{*}{$\begin{array}{l}\text { Observed } \\
\text { range of } \\
\text { shoot No. }\end{array}$} & \multirow{2}{*}{$\begin{array}{c}\text { Mean } \\
\text { leaf } \\
\text { area }\left(\mathrm{cm}^{2}\right)\end{array}$} & \multirow{2}{*}{$\begin{array}{l}\text { Life } \\
\text { form }\end{array}$} & \multirow{2}{*}{$\begin{array}{c}\text { Species } \\
\text { abbre- } \\
\text { viation }\end{array}$} \\
\hline & & $\mathrm{U}$ & G & & & & & \\
\hline Castanopsis acuminatissima A. DC. ex Hance & Fagaceae & 24 & 12 & 19-212 & $1-102$ & 21.3 & $\mathrm{C}$ & $\mathrm{Ca}$ \\
\hline Prunus arborea (Bl.) Kalkm. & Rosaceae & 22 & 9 & 39-227 & $3-49$ & 30.9 & $\mathrm{C}$ & $\operatorname{Pr}$ \\
\hline Lasianthus tomentosus $\mathrm{Bl}$. & Rubiaceae & 16 & 16 & $58-184$ & $3-19$ & 23.3 & S & $\mathrm{La}$ \\
\hline Altingia excelsa Noronha & Hamamelidaceae & 19 & 15 & $19-253$ & $1-21$ & 41.9 & $\mathrm{C}$ & $\mathrm{Al}$ \\
\hline Elaeocarpus petiolatus Wall. & Elaeocarpaceae & 15 & 23 & 41-192 & $1-19$ & 71.0 & $\mathrm{C}$ & El \\
\hline Clidemia hirta (L.) D. Don & Melastomataceae & 9 & 10 & 24-178 & $1-28$ & 48.1 & SS & $\mathrm{Cl}$ \\
\hline $\begin{array}{l}\text { Symplocos cochinchinensis (Lour.) Moore. } \\
\text { ssp. laurina (Retz.) Noot. }\end{array}$ & Symplocaceae & 20 & 19 & 19-211 & $1-6$ & 35.5 & S & Sy \\
\hline Macaranga semiglobosa J. J. S. & Euphorbiaceae & 20 & 12 & $31-225$ & $1-3$ & 149.5 & SC & Ма \\
\hline
\end{tabular}


Table 2. The results of general linear model for the effects of canopy conditions (gap vs understorey), leaf life span (LLS) and the interaction on leaf size of individual leaves, leaf mass per area (LMA), leaf nitrogen concentration per leaf mass ( $\left.N_{\text {mass }}\right)$, per leaf area $\left(N_{\text {area }}\right)$ and height growth rate (HG). Leaf area was used as leaf size. Leaf size and $N_{\text {mass }}$ were ln-transformed and square-root arcsine-transformed before the analysis, respectively. $F_{1,12}$-values are shown with the significance level. Whole-model $R^{2}$ is also shown on the bottom of each column. $* *=\mathrm{P}<0.01, * * *=\mathrm{P}<0.001 . n=16$. Two significant relationships are shown in Figures 1a (LMA), $1 \mathrm{~b}$ ( $\left.N_{\text {mass }}\right)$ and $3 \mathrm{~b}$ (HG).

\begin{tabular}{lcrccc}
\hline Variable & Leaf size & LMA & $N_{\text {mass }}$ & $N_{\text {area }}$ & HG \\
\hline Canopy & 0.64 & 1.68 & 3.11 & 1.65 & $40.46^{* * *}$ \\
LLS & 4.33 & $10.49^{* *}$ & $25.27^{* * *}$ & 2.76 & $16.54^{* *}$ \\
Canopy $\times$ LLS & 0.69 & 0.48 & 3.15 & 0.11 & $10.54^{* *}$ \\
$R^{2}$ & 0.29 & 0.51 & 0.72 & 0.39 & 0.90 \\
& & & & & \\
\hline
\end{tabular}


Table 3. The results of general linear model for the effects of canopy conditions (gap vs understorey), the total length of trunk and branches at $180 \mathrm{~cm}$ trunk height $\left(L_{\mathrm{TB}}\right)$ and the interaction on leaf size of individual leaves, leaf life span (LLS), leaf mass per area (LMA), leaf nitrogen concentration per leaf mass $\left(N_{\text {mass }}\right)$, per leaf area ( $\left.N_{\text {area }}\right)$ and height growth rate (HG). Leaf area was used as leaf size. Leaf size and $N_{\text {mass }}$ were ln-transformed and square-root arcsine-transformed before the analysis, respectively. $F_{1,12}$-values are shown with the significance level. Whole-model $R^{2}$ is also shown on the bottom of each column. $F_{1,10}$-values in parentheses are the statistical results for the height growth rates of the seven species other than subshrub Clidemia hirta $(n=14)$ * $=\mathrm{P}<0.05, * *=\mathrm{P}<0.01 . n=16$. Two significant relationships are shown in Figures 2 (leaf size) and 3a (HG).

\begin{tabular}{lcccccl}
\hline Variable & Leaf size & LLS & LMA & $N_{\text {mass }}$ & $N_{\text {area }}$ & HG \\
\hline Canopy & 0.21 & 0.05 & 0.93 & 0.54 & 1.58 & $8.06^{*}\left(15.56^{* *}\right)$ \\
$L_{\mathrm{TB}}$ & $14.21^{* *}$ & 2.23 & 0.02 & 0.64 & 0.38 & $2.23\left(5.94^{*}\right)$ \\
Canopy $\times L_{\mathrm{TB}}$ & 0.02 & 0.28 & 0.56 & 0.86 & 0.40 & $0.91(2.92)$ \\
$R^{2}$ & 0.55 & 0.21 & 0.09 & 0.14 & 0.28 & $0.75(0.85)$ \\
& & & & & & \\
\hline
\end{tabular}

